\title{
The Role of Benzyl Amino Purine and Kinetin in Enhancing the Growth and Flowering of three Gaillardia Varieties
}

\author{
Ramy Gaber El-Kinany ${ }^{1}$, Atef M. K. Nassar ${ }^{2}$ and Ahmed A.A. El-Settawy ${ }^{3}$ \\ ${ }^{1}$ Department of Horticulture and ${ }^{2}$ Plant Protection Department, Faculty of Agriculture, \\ Damanhour University, Damanhour, El-Beheira, PO Box 59, Egypt, and \\ ${ }^{3}$ Forestry and Wood Technology Department, Faculty of Agriculture (El-Shatby), \\ Alexandira University, Alexandria, Egypt
}

\begin{abstract}
Two pot experiments were carried out during two successive winter seasons of 2015/2016 and 2016/2017 in a private commercial nursery located at Damanhour City, El-Beheira Governorate, Egypt. The objective of this research was to evaluate the effect of two synthetic cytokinins: benzyl amino purine (BAP) at 50 and $100 \mathrm{ppm}$ and 6-furfuryl-aminopurine (kinetin) at 25 and $50 \mathrm{ppm}$, each alone, on the growth performance, yield and quality of three varieties (pulchella, Mesa Yellow and Lorenziana) of gaillardia (Gaillardia pulchella). The experiment was designed as a split-plot design containing three replicates. The obtained results of the two seasons, generally, revealed that Gaillardia pulchella var. pulchella had the highest plant and flowering growth parameters, (viz. number of inflorescence per plant and flowering duration). While, Lorenziana variety showed the best diameter, longevity, fresh weight and dry weight of inflorescence per plant. Spraying gaillardia plants with BAP and kinetin significantly enhanced vegetative, root and flowering parameters compared to the control treatment. From that, BAP at $100 \mathrm{ppm}$ or kinetin at $25 \mathrm{ppm}$ recorded the highest mean values of the most recorded data and might be considered as optimal treatment for the production of high yield and quality of gaillardia plants under the environmental conditions of El-Beheira Governorate and other similar regions.
\end{abstract}

Keywords: Plant growth regulators, Cytokinin, BAP, kinetin, Gaillardia.

\section{INTRODUCTION}

Gaillardia (Gaillardia pulchella), a member of the family Asteraceae, is native to Florida and Central and Western United States (Anonymous, 2007). Its common name is blanket flower and it may have come from the resemblance of the flowers to brightly patterned Native American. The generic name Gaillardia stands in honor of M. Gaillard, a French patron of botany (Baily, 1947). Gaillardia is a flowering herbaceous annual or short-lived perennial (Helen et al., 2007). The annual gaillardia is propagated by seeds. The perennial forms can be propagated by cutting, division or seeds. Gaillardia popularly cultivated for its attractive colour flowers and for varied uses like cut flowers, making garlands, floral decorations and required on weddings, religious occasions, excellent for raising in garden as borders and beds and other ceremonial and social occasions. Gaillardia produces flowers in a wide range of colors such as orange, yellow, scarlet, cream, bronze, red and brick-red and can be grown all around the year (Shreedhar, 1993). Gaillardia flowers are small and numerous; born in solitary, usually showy heads which is stated as capitulam with 4 to $6 \mathrm{~cm}$ in diameter. Individual flowers in a capitulam are called florets which range from one to ten according to cultivar or genotype. As a member of Asteraceae it has both ray and disc florets which are pistillate and hermaphrodite, respectively in nature. Flower has a long hairy stalk and single, semi- double and double types with single or multicolored heads (Cox and Klett, 1984). Presently the area under this crop is less and it is likely to be increased in the near future because this is a heavy demand for its flowers. However, the yield of flowers and its quality are low, which need to be increased by adopting improved agro techniques like using plant growth regulators.

The most important types of plant growth regulator classes are grouped into plant growth promoters such as auxins, gibberellins, and cytokinins. In addition, plant growth inhibitors such as abscisic acid and ethylene.

Plant growth regulators at small amounts can adjust plant physiological process and play a vital role in plant growth and development, such as elongation and flower development (Yamaguchi and Kamiya, 2000). Control of flowering is one of the most important practical aspects in application of plant growth regulators. There are numerous examples of utilization of plant growth regulators, which can regulate the flowering in aromatic plant (Shukla and Farooqi, 1990), for example, application of Ethrel (2-Chloroethyl phosphonic acid), kinetin and NAA (Naphthalene acetic acid) improved flowering in Rosa damascena and Jasminum Sambac (Farooqi and Sharma, 1988; Sharma and Farooqi, 1990; Farooqi et al., 1993). Performance of plant growth regulators applied depends on; the application method, amount of active ingredient presents and the time of application. The correct application method will ensure proper coverage of all tissues or targets the 
responsible tissue. The most common method is a foliar application as it is easy, convenient, cheap and economical.

Plant growth regulators like cytokinins playing a vital role from seed germination to senescence stage, which enable to prolonging the vase life and delaying the onset of senescence (Chatsudthipong and Muanprasat, 2009). Cytokinins can be utilized in variety of applications, from the treatment of seeds (Riedell et al., 1985) to applications during flowering (Dyer et al., 1986). Synthetic Cytokinins such as 6-furfuryl-aminopurin (kinetin) and benzyl amino purine (BAP) can improve plant growth by increasing cell division, break bud dormancy and promote the growth of the lateral buds (Hossain et al., 2006). Application of synthetic cytokinin on shoot increased chlorophyll formation and protein synthesis within tissues (George et al., 2008). However, available literature has no reports so far regarding the effect of cytokinins on growth and flowering of Gaillardia particularly in Egypt. Keeping these facts in view, an experiment was conducted with following objectives:

1. Trying to enhancement flower size and quality and increase the flower longevity.

2. To evaluate the effect of two synthetic cytokinin types and levels (BAP and Kin) each alone; on growth performance, yield and quality of flowers of the three varieties of Gaillardia.

\section{MATERIALS AND METHODS}

\section{Greenhouse experimental design}

Two pot experiments were carried out during the two successive winter growing seasons, 2015/2016 and 2016/2017. The experiments were accomplished in a private commercial nursery located at Damanhour city in Beheira Governorate, Egypt under greenhouse conditions. Gaillardia varieties used during the study were Pulchella, Mesa Yellow (both varieties have flower head appear single with either a classic daisy form) and Lorenziana (The central disc filled with trumpetshaped, 5-petaled flowers)". These varieties were chosen because of there fame. Seeds of Gaillardia were obtained from Ontario Seeds Company Ltd. Waterloo, Ont., Canada. Seeds were sown on 15 October in both seasons in $25 \mathrm{~cm}$ black plastic pots filled with soil consist of sand, silt, and clay as appeared in Table (1). After seed germination, plants were thinned to one plant per pot.

Soil samples were collected then physically and chemically analyzed according to Black et al. (1965). The analyses were carried out at the Natural Resourcse and Engineering Soil Department, Agriculiture Faculty, Damanhour University.
Table 1: Physical and chemical analyses of soil samples of the experiment.

\begin{tabular}{lcc}
\hline Physical analysis & $\begin{array}{c}\text { First } \\
\text { season }\end{array}$ & $\begin{array}{c}\text { Second } \\
\text { season }\end{array}$ \\
\hline Clay (\%) & 0.77 & 0.72 \\
\hline Silt (\%) & 7.00 & 8.03 \\
\hline Sand (\%) & 92.23 & 91.25 \\
\hline Texture class & sand & sand \\
\hline Chemical analysis & & \\
\hline $\mathrm{EC}(\mathrm{dS} / \mathrm{m})$ & 0.80 & 0.87 \\
\hline $\mathrm{pH} \quad 7.90$ & 7.80 \\
\hline $\mathrm{Ca}(\mathrm{meq} / \mathrm{L})$ & 20.10 & 20.52 \\
\hline $\mathrm{Mg}(\mathrm{meq} / \mathrm{L})$ & 6.23 & 6.98 \\
\hline $\mathrm{SO}{ }_{4}(\mathrm{meq} / \mathrm{L})$ & 8.21 & 7.98 \\
\hline $\mathrm{K} \mathrm{(meq/L)}$ & 5.23 & 5.35 \\
\hline \multicolumn{1}{c}{ Aqueous solutions } & of Benzyl amino purine
\end{tabular}

(BAP) and kinetin (manufactured by the SigmaAldrich Corporation) were applied as foliar spray at the concentrations of 50, and $100 \mathrm{ppm}$ for (BAP) and 25 and 50 ppm for Kinetin and Distilled water was used as a control. The pot surface was covered with polyethylene before application to avoid falling of spray drips on the growing medium. All cytokinin concentrations were applied using a hand sprayer and non-ionic surfactant tween 80 at $0.05 \%$ $(\mathrm{v} / \mathrm{v})$ was added to all treatments to reduce the surface tension and increase the contact angle of sprayed droplets. Each plant was sprayed individually, so that, all foliage was moistened until the point of run-off. The spraying volume was 25 $\mathrm{ml}$ per plant. The untreated control plants were sprayed with distilled water.

Spraying plants was applied two times; the first one was carried out at flower initiation phase (Saffari et al., 2004 and Khatun et al., 2016), almost after five monthes from seed sowing. The second application was done 7 days after the first one.

The reason behind spraying gaillardia plants with cytokinin components when the plants entered flower initiating phase is due to the fact that spraying plants with cytokinins at the beginning of the plant life and the plant still small, leads to elongation in the plant cells and increases number of lateral branches and due to the nature of blanket flower growth where the plant is considered a tall herbaceous annual (more than $1 \mathrm{~m}$ long), which is usually subjects to slanting if it was grow alone in pot (Noor El-Deen et al., 2014). Also, the yield of flowers and its quality will be low because of the apical dominance which limits the production of flowers and reduces its quality. So the aim of this study was increasing the quality of flowers by increasing flower size and flower longevity or vase life which are the most important characters for commercial value of flowers (Saifuddin et al., 2009). 
All cultural practices were applied whenever they were necessary and as commonly recommended in the commercial production of gaillardia. Irrigation was done as needed.

\section{The following data were recorded:}

\section{Plant growth characters}

Three plants from each treatment in each replicate were randomly chosen and tagged for collect vegetative growth traits, notably; plant height $(\mathrm{cm})$ which was recorded from the first week of treatments application (almost five months after sowing of the seeds), number of branches per plant, leaf area $\left(\mathrm{cm}^{2}\right)$ according to Zidan (1962), shoot fresh and dry weights per plant $(\mathrm{g})$ were determined without the inflorescences and also for roots by the end of the experiment for all plants. Dry weights were determined by drying the plant samples in the oven at $70{ }^{\circ} \mathrm{C}$ till obtaining a constant weight, then left to cool inside the oven and weighed in grams. In all cases, the weight measurements were performed using a digital scale with a precision of 0.001 digits. Also, root growth parameters were measured such as root length, root fresh and dry weights per plant (g).

\section{Flowering growth characters}

Flowering growth parameters were measured such as; inflorescence diameter $(\mathrm{cm})$, flowering duration (day), number of inflorescences per plant, inflorescence longevity on the plant and inflorescence fresh weight $(\mathrm{g}$; all fully opened inflorescences per plant before the beginning of fading stage were used), and inflorescence dry weight $(\mathrm{g})$ were estimated according to Elkinany (2016).

The experimental design and statistical analysis

The experiments were designed as a split plots design with three replicates (Snedecor and Cochran, 1967). Where, the three varieties of gaillardia were arranged as the main plots, and the synthetic cytokinins concentrations were considered as sub-plots. Data were analyzed by Statistical Analysis Systems (CoStat, 2008) and the means were compared by Tukey multiple comparison posthoc test at 0.05 probability.

\section{RESULTS AND DISCUSSION}

\section{Vegatative characters}

Data in Table (2) showing the main effects of the two studied factors (Three varieties of gaillardia and different levels of synthetic cytokinins) on plant growth parameters of gaillardia plants during the two growing seasons of 2015/2016 and 2016/2017.

Regarding the main effect of three gaillardia varieties on plant growth parameters, data in Table (2) indicated that the three gaillardia varieties significantly differed in their vegetative growth paramaters. Pulchella variety showed the highest mean values of plant height, number of branches per plant, leaf area, shoot fresh weight and dry weights per plant, root length and root fresh and dry weights per plant in both seasons. However, there was no significant difference between the two gaillardia varieties "Pulchella and Mesa yellow" in plant height during the first season, in number of branches per plant in both season and root length in the second season. Moreover, there was no significant difference among the three varieties of gaillardia "Pulchella, Mesa Yellow and Lorenziana" in leaf area, shoot fresh weight per plant and root fresh weight per plant in the second season. The detected differences among the three tested varieties could be attributed to their genetic features.

Concerning the main effect of different rates of synthetic cytokinins (BAP and kinetin) on plant growth parameters, data in Table (2) indicated that, spraying gaillardia plants with benzyl amino purine (BAP) and kinetin in general significantly increased vegetative growth parameters compared to control treatment. Spraying plants with BAP at $100 \mathrm{ppm}$ gave the highest mean values of plant height, number of branches per plant, leaf area, shoot fresh and dry weights per plant during both seasons compared to the control treatments. However, there was no significant difference between the two concentrations of $\operatorname{BAP}(50$, and $100 \mathrm{ppm})$ in number of branches per plant and leaf area in both seasons. On the other hand, spraying with kinetin significantly increased root growth parameters i.e. root length, root fresh weight per plant and root dry weight per plant in both seasons compared to the control treatment.

Results also indicated that the low concentration of kinetin (25 ppm) was more effective than the high concentration of kinetin (50 ppm) in increasing root growth parameters. However, there was no significant difference between the two concentrations of kinetin (25 and $50 \mathrm{ppm}$ ) for leaf area in the first season, shoot dry weight per plant in the second season and root fresh and dry weights per plant in the second season.

Generally, the superior influence of benzyl amino purine (BAP) treatments on stimulating the vegetative growth parameters may be due to the role of BAP in stimulating cell division and elongation (Krug et al., 2006, Mazher et al. 2011, and Sadak et al., 2013), which leads to stimulation of primordial production and partially intermodal elongation on the apex (Kumari, 2017), which reflected in the increase of plant height. Cytokinins play an important role in counteracting or eliminating the apical dominance and stimulating the release of axillary buds from apical dominance (Sachs and Thimann, 1964, 1967; Tamas, 1995; Arteca, 1996 and Menaka et al., 2018) which lead to increment in number of branches per plant. 


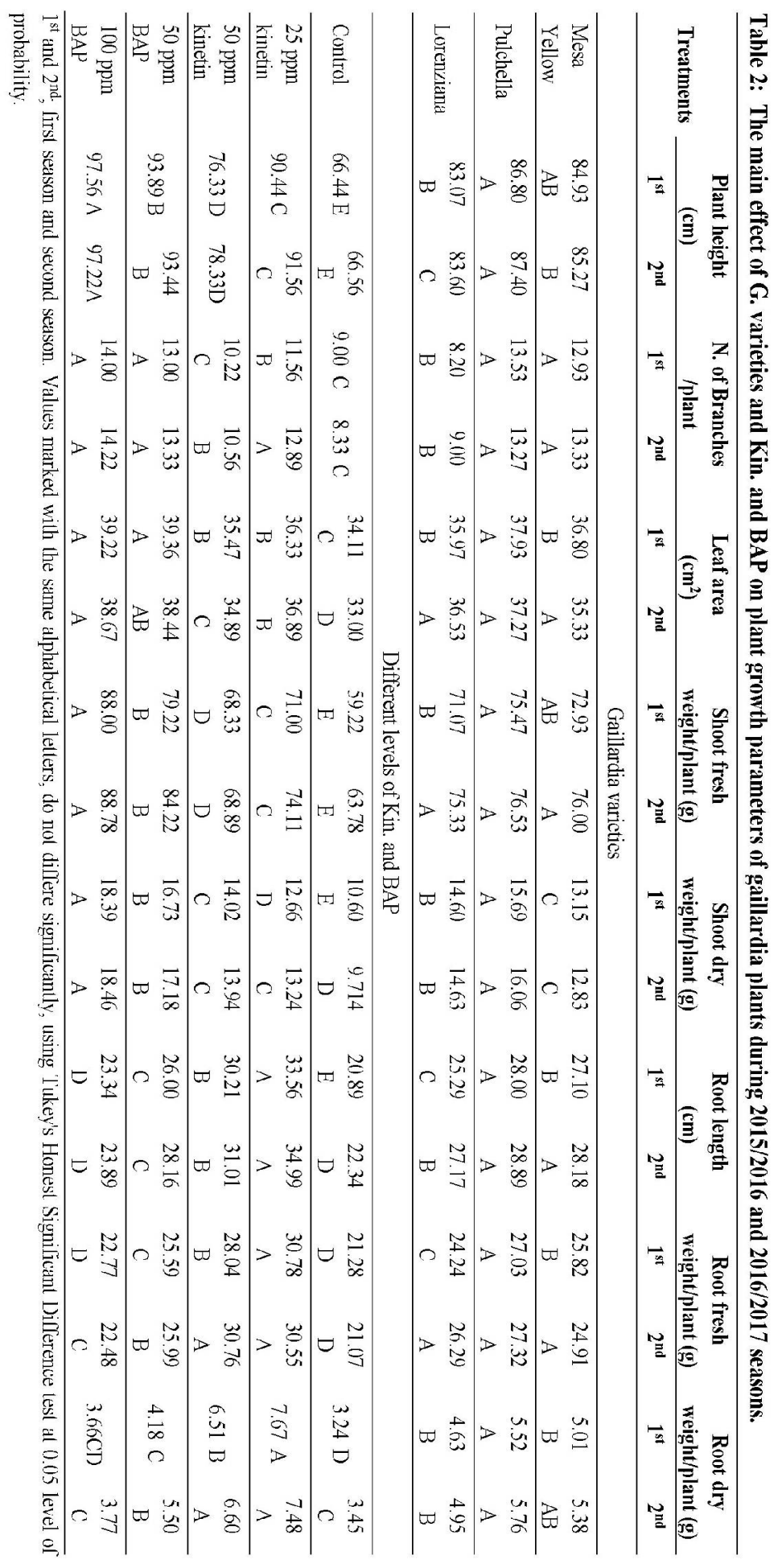


The obtained results are comparable with those obtained by Eid and Abou-Leila (2006) on Coroton plant, Mara (2017) on Echinacea Hybrids and Mazher et al., (2011) on Codiaeum variegatum L., Sharief and El-hamady (2017) on Broad Bean and Khandaker et al. (2018) on stevia plants.

Cytokinins are considered a growth control hormones, which promote protein synthesis, cell division, enlargement, cell number and nutrient mobilization (Zhao et al., 2010 and Bairwa and Mishra, 2017). When exogenous applications of Cytokinins are made, they promote cell expansion (Miller, 1956) which leads to increasing the leaf area. The general increase in leaf area as a result of BAP treatments is in agreement with the findings of Reda et al., (2010) on chamomile plant, Henschke et al., (2015) on Helleborus Orientalislam 'Red Hybrids', Mansour et al., (2016) on Conocarpus erectus L. Plants, Mara (2017) on Echinacea Hybrids and Mohamed (2017) on aster plant.

The increment in the shoot fresh weight could be explained through the role of cytokinin in stimulating xylem differentiation and vascular strand development, which lead to more absorption of water and nutrients from the soil, which was reflected in more growth, as mentioned by Sorokin and Thimann (1964). These results are in harmony with those obtained by Eid and Abou-Leila (2006) on Coroton plant, Abdel El-Aziz (2007) on Codiaeum variegatum L., Ghatas (2015) on Hemerocallis aurantiaca and Neetu and Singh (2016) on gladiolus. Similar increases in the dry weight of shoot as a result of BAP treatments have been reported by Mazrou (1992) on Datura innoxia plants, Zaghloul (1998) on Codiaeum variegatum and Cordyline terminalis and Mansour et al., (2016) on Conocarpus erectus L. plants.

The positive effect of kinetin on stimulating the root growth parameters may be due to accumulation of greater photosynthates which leading to better growth parameters (El-Keltawi and Croteau, 1987) and the role of kinetin in stimulation of the cell division, enlargement and number (Schmulling, 2002 and Khalighi et al., 2005) which leading to increase root length and number of offsets and then increasing root growth parameters. Our results are in harmony with those of Sardoei et al., (2013) on Aloe barbadensis, Aier et al., (2015) on Gladiolus Cv. Red Candyman, Hembrom and Singh (2015) on Lilium, Ghatas (2015) on Hemerocallis aurantiaca and El-Bably and Rashed (2017) on Clivia miniata.

The interaction effect between the three gaillardia varieties and different levels of BAP and kinetin on plant growth parameters were significant during both seasons (Table 3). The statistical analysis revealed that the highest mean values of plant height recorded at the combined treatment of the three gaillardia varieties "Pulchella, Mesa Yellow and Lorenziana" with 100 ppm BAP treatment. The combined treatment of Pulchella variety with 100 ppm BAP treatment recorded, generally, the highest mean values of number of branches per plant, leaf area, shoot fresh and dry weights in both seasons compared to the control treatment. However, the highest mean values of root length were obtained when Lorenziana cultivar sprayed with 25 ppm kinetin in both seasons. On the other hand the combined treatment which included Pulchella variety with $25 \mathrm{ppm}$ kinetin recorded the highest mean values of root fresh and dry weights, in the both seasons. The 100 ppm BAP level increased number of branches per plant, leaf area , shoot fresh weight and shoot dry weight of Pulchella variety by (62.14 and $81.11 \%),(15.85$ and 20.12 $\%),(35.3 \%$ and $38 \%)$ and $(78.38 \%$ and $86.67 \%)$ over than the control treatment for the first and second seasons, respectively. Also, 25 ppm kinetin level, increased root fresh and dry weights of Pulchella variety by $(48.8 \%$ and $56.52 \%)$ and $(94.6 \%$ and $119.44 \%)$ over than the control treatment for the first and second seasons, respectively.

\section{Flowering growth characters}

Concerning the main effect of the three gaillardia varieties on flower parameters, the gained results presented in Table (4) showed that the three gaillardia varieties significantly differed in inflorescence characters. Lorenziana variety showed highest mean values of the most data recorded i.e. inflorescence diameter, inflorescence fresh and dry weight per plant and inflorescence longevity in both seasons. While, Pulchella variety showed highest mean values of number of inflorescences per plant and flowering duration in both seasons. However, there was no significant difference between the two gaillardia varieties "Lorenziana and Pulchella" in inflorescence diameter in both seasons and "Pulchella and Mesa Yellow" varieties in number of inflorescence per plant in the first season only. The detected difference among three gaillardia varieties could be attributed to their genetic features.

Regarding the main effect of different rates of BAP and kinetin on flowering growth parameters, data in Table (4) indicated in general that, spraying gaillardia plants with kinetin and benzyl amino purine (BAP) significantly increased flowering growth parameters compared to control treatment. The obtained data indicated that spray plants with kinetin gave the highest mean values of inflorescence diameter, number of inflorescence per plant, inflorescence fresh and dry weight per plant, inflorescence longevity and flowering duration. 


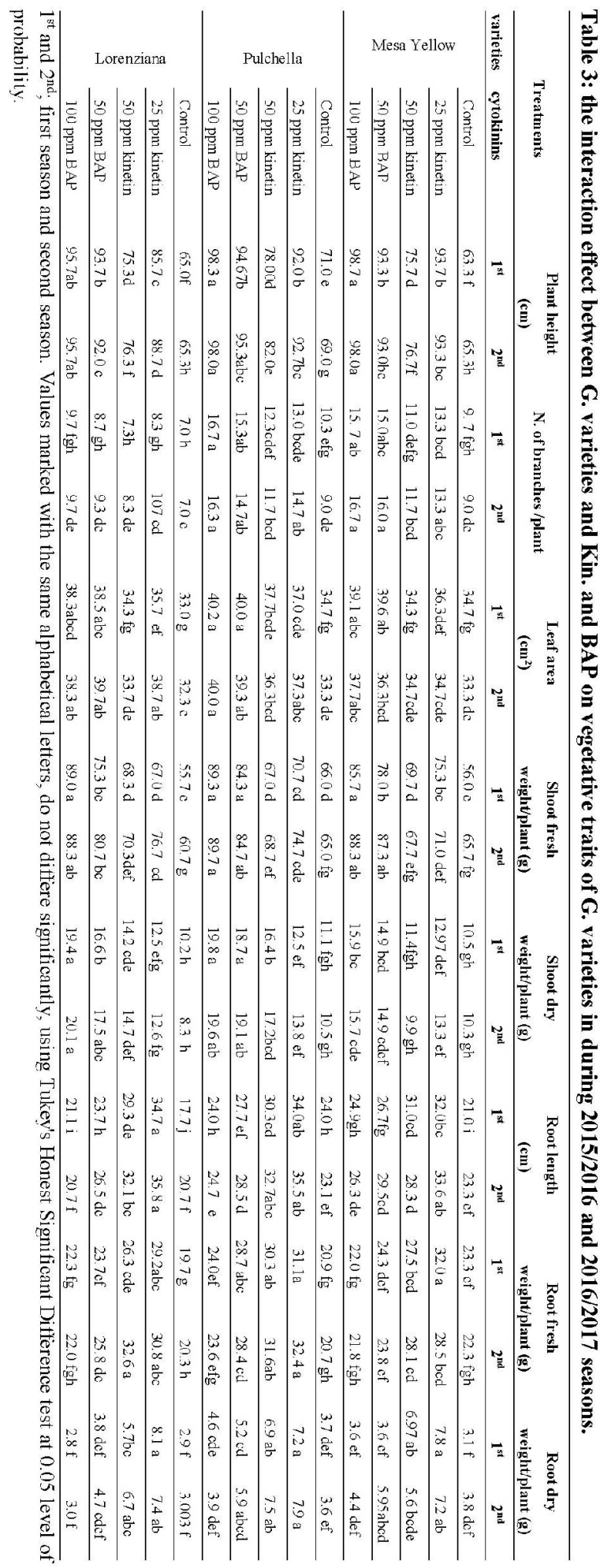


Table 4: The main effect of G. varieties and Kin. and BAP on flowering parameters of gaillardia plants during 2015/2016 and 2016/2017 seasons.

\begin{tabular}{|c|c|c|c|c|c|c|c|c|c|c|c|c|}
\hline \multirow[t]{2}{*}{ Treatments } & \multicolumn{2}{|c|}{$\begin{array}{l}\text { Inflorescence } \\
\text { diameter } \\
(\mathrm{cm})\end{array}$} & \multicolumn{2}{|c|}{$\begin{array}{c}\text { N. of } \\
\text { inflorescences } \\
\text { / plant }\end{array}$} & \multicolumn{2}{|c|}{$\begin{array}{c}\text { Inflorescence } \\
\text { fresh } \\
\text { weight/plant } \\
\text { (g) }\end{array}$} & \multicolumn{2}{|c|}{$\begin{array}{c}\text { Inflorescence } \\
\text { dry } \\
\text { weight/plant } \\
\text { (g) }\end{array}$} & \multicolumn{2}{|c|}{$\begin{array}{c}\text { Inflorescence } \\
\text { longevity } \\
\text { (day) }\end{array}$} & \multicolumn{2}{|c|}{$\begin{array}{l}\text { Flowering } \\
\text { duration } \\
\text { (day) }\end{array}$} \\
\hline & $1^{\text {st }}$ & $2^{\text {nd }}$ & $1^{\text {st }}$ & $2^{\text {nd }}$ & $1^{\text {st }}$ & $2^{\text {nd }}$ & $1^{\text {st }}$ & $2^{\text {nd }}$ & $1^{\text {st }}$ & $2^{\text {nd }}$ & $1^{\text {st }}$ & $2^{\text {nd }}$ \\
\hline \multicolumn{13}{|c|}{ Gaillardia varieties } \\
\hline Mesa & 5.05 & 5.43 & 24.33 & 23.67 & 2.12 & 2.25 & 0.94 & 0.903 & 5.53 & 5.67 & 73.53 & 71.07 \\
\hline Yellow & $\mathrm{B}$ & $\mathrm{B}$ & A & $\mathrm{B}$ & $\mathrm{C}$ & $\mathrm{C}$ & $\mathrm{C}$ & $\mathrm{C}$ & $\mathrm{C}$ & $\mathrm{B}$ & $\mathrm{C}$ & $\mathrm{C}$ \\
\hline \multirow{2}{*}{ Pulchella } & 5.91 & 5.79 & 24.40 & 25.60 & 2.38 & 2.57 & 1.17 & 1.18 & 6.20 & 6.07 & 91.07 & 92.67 \\
\hline & A & $\mathrm{A}$ & A & A & $\mathrm{B}$ & $\mathrm{B}$ & $\mathrm{B}$ & $\mathrm{B}$ & $\mathrm{B}$ & $\mathrm{B}$ & A & A \\
\hline \multirow{2}{*}{ Lorenziana } & 5.70 & 5.87 & 15.00 & 14.47 & 3.6 & 3.88 & 1.80 & 1.93 & 13.8 & 13.93 & 81.13 & 82.47 \\
\hline & $\mathrm{A}$ & $\mathrm{A}$ & $\mathrm{B}$ & $\mathrm{C}$ & $\mathrm{A}$ & $\mathrm{A}$ & $\mathrm{A}$ & $\mathrm{A}$ & $\mathrm{A}$ & $\mathrm{A}$ & $\mathrm{B}$ & $\mathrm{B}$ \\
\hline \multicolumn{13}{|c|}{ Different levels of Kin. and BAP } \\
\hline \multirow{2}{*}{ Control } & 4.47 & 4.48 & 17.56 & 16.44 & 2.45 & 2.46 & 0.91 & 1.05 & 6.44 & 6.44 & 70.00 & 74.44 \\
\hline & $\mathrm{C}$ & $\mathrm{C}$ & $\mathrm{C}$ & $\mathrm{C}$ & $\mathrm{C}$ & $\mathrm{C}$ & $\mathrm{D}$ & $\mathrm{C}$ & $\mathrm{C}$ & $\mathrm{C}$ & $\mathrm{C}$ & $\mathrm{D}$ \\
\hline $25 \mathrm{ppm}$ & 6.29 & 6.58 & 25.22 & 25.00 & 2.94 & 3.15 & 1.71 & 1.54 & 10.00 & 9.78 & 89.89 & 89.67 \\
\hline kinetin & $\mathrm{A}$ & $\mathrm{A}$ & $\mathrm{A}$ & A & $\mathrm{A}$ & $\mathrm{A}$ & $\mathrm{A}$ & $\mathrm{A}$ & $\mathrm{A}$ & $\mathrm{A}$ & $\mathrm{A}$ & $\mathrm{A}$ \\
\hline $50 \mathrm{ppm}$ & 6.16 & 6.52 & 23.56 & 24.33 & 2.89 & 3.10 & 1.42 & 1.47 & 9.56 & 9.33 & 89.22 & 86.11 \\
\hline kinetin & $\mathrm{A}$ & $\mathrm{A}$ & $\mathrm{AB}$ & $\mathrm{A}$ & $\mathrm{A}$ & $\mathrm{A}$ & $\mathrm{B}$ & $\mathrm{A}$ & $\mathrm{A}$ & $\mathrm{A}$ & $\mathrm{A}$ & $\mathrm{AB}$ \\
\hline $50 \mathrm{ppm}$ & 5.79 & 5.31 & 21.56 & 21.89 & 2.63 & 3.05 & 1.37 & 1.41 & 8.44 & 9.11 & 84.00 & 82.67 \\
\hline BAP & $\mathrm{A}$ & $\mathrm{B}$ & $\mathrm{B}$ & $\mathrm{AB}$ & $\mathrm{B}$ & $\mathrm{A}$ & $\mathrm{B}$ & $\mathrm{AB}$ & $\mathrm{B}$ & $\mathrm{A}$ & $\mathrm{AB}$ & $\mathrm{BC}$ \\
\hline $100 \mathrm{ppm}$ & 5.08 & 5.62 & 18.33 & 18.56 & 2.59 & 2.75 & 1.11 & 1.21 & 8.11 & 8.11 & 76.44 & 77.44 \\
\hline BAP & $\mathrm{B}$ & $\mathrm{B}$ & $\mathrm{C}$ & $\mathrm{BC}$ & $\mathrm{BC}$ & $\mathrm{B}$ & $\mathrm{C}$ & $\mathrm{BC}$ & $\mathrm{B}$ & $\mathrm{B}$ & $\mathrm{BC}$ & $\mathrm{CD}$ \\
\hline
\end{tabular}

$1^{\text {st }}$ and $2^{\text {nd }}$; first season and second season. Values marked with the same alphabetical letters, do not differe significantly, using Tukey's Honest Significant Difference test at 0.05 level of probability.

Also, there was no significant difference between the two concentrations of kinetin $(25$, and $50 \mathrm{ppm})$ in inflorescence diameter, number of inflorescences per plant, inflorescence fresh weight per plant, inflorescence longevity, flowering duration in both seasons, and inflorescence dry weight per plant in the second season.

Generally, the greater influence of kinetin treatments on stimulating the flowering growth parameters may be due to the role of kinetin in promoting protein synthesis, increasing cell division, enlargement and chlorophyll synthesis (Cheema and Sharma, 1982). Which lead to an increase in flower diameter. These results are comparable with those obtained by El-Bably and Rashed (2017) on Clivia miniata. L. plants, Bairwa and Mishra (2017) on African Marigold (Tagetes erecta Linn.) and Abou-El-Ghait et al., (2018) on Dendranthema grandiflorium cv. Art Queen plants.

The increment in number of inflorescences per plant with kinetin treatment could be due to delay of senescence which enhanced the translocation of photosynthesis from source to sink (Salisbury and Ross, 1974 and Hugar and Nalawadi, 1999). The obtained results of number of inflorescence per plant are in harmony with those reported by Bairwa and Mishra (2017) on African Marigold (Tagetes erecta Linn.), El-Bably and Rashed (2017) on Clivia miniata. L. plants, Mara (2017) on Echinacea Hybrids and Mohamed (2017) on aster plant.

Kinetin playing a vital role in promoting protein synthesis, increasing cell division and enlargement and chlorophyll synthesis (Cheema and Sharma, 1982) which lead to an increase in inflorescence diameter and, then increment of inflorescence fresh and dry weights. Results of inflorescence fresh weight and flower dry weight per plant are comparable with those obtained by Youssef (2004) on Strelitzia reginae, Youssef and Ismaeil (2009) on Livia minister plant, Ghatas (2015) on Hemerocallis aurantiaca and El-Bably and Rashed (2017) on Clivia miniata. L.

The increased longevity of kinetin-treated inflorescence may be due to its effect on ethylene synthesis processes in the tissue of flowers and decreases the ethylene production within the flowers (Bosse and Van Staden, 1989) and decreasing of protein hydrolytic enzymes activity lipooxygenase (Leshem et al., 1979). Also, it may attributed to its role in decreaseing the respiration rate of kinetintreated flowers (MacLean and Dedolph, 1962). The superior influence of kinetin on increasing flowering duration may be due to the increasing of inflorescence number and inflorescence longevity. 


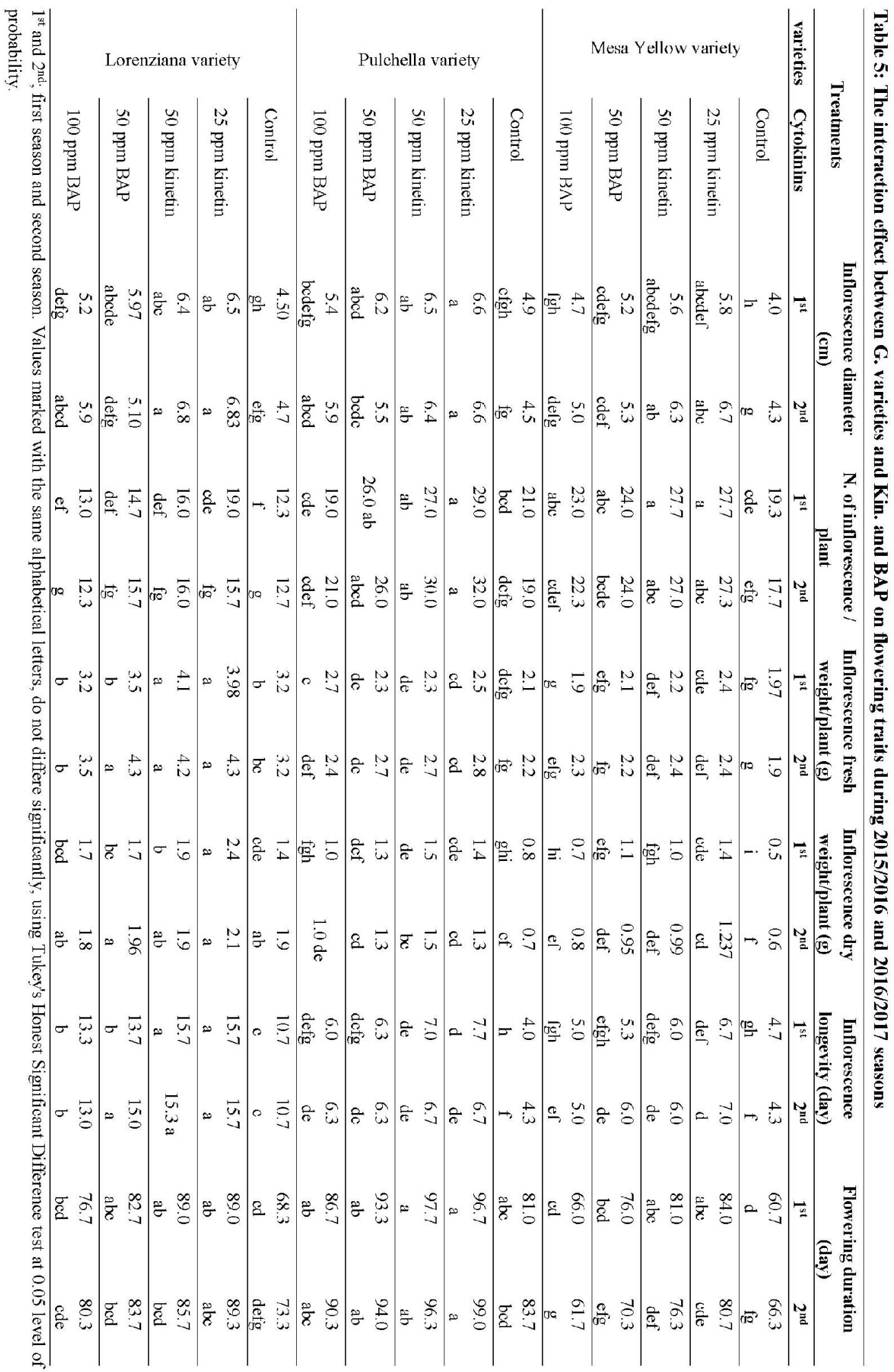


The general increase in inflorescence longevity and flowering duration as a result of kinetin treatments is in agreement with the findings of Reda et al., (2010) on chamomile plant, Mara (2017) on Echinacea Hybrids, Mohamed (2017) on Symphyotrichum novi-belgii L. and Abou-El-Ghait et al., (2018) on Dendranthema grandiflorium cv. Art Queen plants.

The effects of interaction between the gaillardia varieties and different levels of BAP and kinetin on flowering growth parameters of gaillardia plants were significant during both seasons (Table 5). The obtained results, generally, revealed that the combined treatment which included Pulchella variety and $25 \mathrm{ppm}$ kinetin gave the highest mean values of inflorescence diameter, number of inflorescences per plant and flowering duration in the both seasons. Whereas, the combined treatment of the Lorenziana variety and either 25 or $50 \mathrm{ppm}$ kinetin presented the highest mean values of inflorescence fresh weight, inflorescence dry weight and inflorescence longevity in both seasons. The estimated percentages increase in inflorescence diameter, number of inflorescences per plant and flowering duration for Pulchella variety were (34.69 and $46.67 \%)$, (38.1 and $68.42 \%)$ and (19.38\% and $18.28 \%$ ) compared to the control treatment for the first and second seasons, resiectively. Whereas, the estimated percentages increase in inflorescence fresh weight, inflorescence dry weight and inflorescence longevity for Lorenziana variety were (24.38, 28.13 and $34.38,31.25 \%),(71.43$ and 10.53 , $3.16 \%)$ and $(46.73 \%$ and $46.73,42.99,40.19 \%)$ compared to the control treatment for the first and second seasons, resiectively.

\section{CONCLUSIONS}

This study recommends, generally, that the interaction between Pulchella variety and either BAP at $100 \mathrm{ppm}$ or kinetin at $25 \mathrm{ppm}$ considerd as a best treatment for the production of admirable vegetative and flowering growth of gaillardia plants under the environmental conditions of this study.

\section{REFERENCES}

Abd El-Aziz, N. 2007. Stimulatory effect of NPK fertilizer and benzyladenine on growth and chemical constituents of Codiaeum variegatum L. American-Eurasian J. of Agri \& Envi. Sci. 2(6): 711-719.

Abou-El-Ghait, E. M, Gomaa, A. O., Youssef, A. S. M. and EL-Nemr, A. M. 2018. Effect of kinetin and GA3 treatments on growth and flowering of Dendranthema grandiflorium cv. Art Queen plants. Middle East J. Agric. Res., 7(3): 801-815.
Aier, Sh., Langthasa, S., Hazarika, D. N., Gautam, B.P. and Goswami, R.K. 2015. Influence of GA3 and BA on morphological, phenological and yield attributes in Gladiolus $\mathrm{Cv}$. Red Candyman. J. Agri \& Vet. Sci (IOSR)., (8): 6, 37-42.

Anonymous: U.S. department of agriculture. The plant database (2007).

Arteca, R. N. 1996. Plant Growth Substances: Principles and Applications, Chapman \& Hall, New York. 133: 67- 69.

Baily, L. H. 1947.The standard encyclopadia of horticulture. The Macmillan Company.

Bairwa, S and Mishra, J. S. 2017. Effect of NAA, BA and Kinetin on Yield of African Marigold (Tagetes erecta Linn.). Int.J.Curr.Microbiol.App.Sci. 6(6): 1236-1241.

Black, C.A., Evans, D.D. and Dinauer, R.C. 1965. Methods of soil analysis. Madison, WI: Amer. Soc. of Agron., 9: 653-708.

Bosse, C. A and Van Staden, J. 1989. Cytokinin in cut carnation flowers. V- Effect of cytokinin type, concentration and mode of opplication on flower longevity. C. F. Hort., Abst.,60: (6304).

Chatsudthipong, V and Muanprasat, C. 2009. Stevioside and related compounds: therapeutic benefits beyond sweetness. Pharmacology \& Therapeutics, 121(1): 41-54.

Cheema, G.S. and Sharma, D.P. 1982. In vitro propagation of apple rootstocks. Int. Hort. Congr XXI. Hamburg, German Federal Republic, Int. Soc. Hort. Sci. 1: 1035 (C.F. Chem. Abst., 52: 7692).

CoStat. 2008. CoStat program, version 6.4. CoHort Software, Monterey, CA., USA.

Cox, R. A. and Klett, J. E. 1984. Evaluation of some indigenous western plants for xeric landscape. Hort. Sci., 19: 856-858.

Dyer, D. J., Carlson, D. R., Cotterman, C. D., Sikorski, J. A. and Ditson, S. L. 1986.Soybean pod set enhancement with synthetic cytokinin analogs. Plant Physiol. 84: 240-243.

Eid, R. A and Abou-Leila, B. H. 2006. "Response of croton plants to gibberellic acid, benzyl adenine and ascorbic acid application." World J. Agric. Sci 2.2: 174-179.

El-Bably, S.M. and Rashed, M., 2017. Effect of Kinetin and Zinc Foliar Spray on Growth Performance of Clivia miniata. L. Plant. Alexandria Journal of Agricultural Sciences, 62 (6).

El-Keltawi, N. E and Croteau, R. 1987. Influence of foliar applied cytokinin on growth and essential oil content of several members of the Lamiacea. Phytochem., 26: 891-895.

Elkinany, R. G. 2016. Possibility of enhancing commercial characteristics of zinnia (Zinnia elegans 1.) by using cycocel. J. Agric. \& Env. Sci. Damanhour University. 15(2): 85-98. 
Farooqi, A. H and Sharma, S. 1988. Effect of growth retardants on flowering of Rosa damascene. In: Proc. Int. Cong. of Plant Physiol: 1369-72.

Farooqi, A. H., Sharma, S., Naqvi, A. A. and Khan, A. 1993. The effect of Kinetin on flower and oil production in Rosa damascena. J. Essent. Oil Res., 5: 305-9.

George, E. F., Hall, M. A. and De Klerk, G. J. 2008. Plant Propagation by Tissue Culture 3rd Edition, Vol. 1. Springer, Dordrecht, The Netherlands: $501 \mathrm{p}$.

Ghatas, Y. A. 2015. Response of Hemerocallis aurantiaca plants to kinetin and chemical fertilization treatments. Middle East Journal of Agriculture Research., 4(4): 650-659.

Helen, D, H. , Richard, K. S., Sandra, B. W. and Jeffrey, G. N. 2007. Evaluation of gaillardia cultivars and ecotypes for landscape performance in North-Central Florida.SNA. Res. conference, 52: 204-209.

Hembrom, R. and Singh, A.K. 2015. Effect of iron and zinc on growth, flowering and bulb yield in Lilium. Inter. J. Agric, Envi and Biotech., 8(1): 61-64.

Henschke, M, Czuchaj, P. K. and Szczepaniak, S. J. 2015. The effect of benzyladenine and gibberellic acid on growth and flowering of Helleborus Orientalislam. Bulgarian J. Agri. Sci, 21 (6): 1198-1203.

Hossain, M. S, Rahman, M. M., Rashid, M. R., Farid, A. T. M., Kaium, M. A., Ahmed, M., Alam, M. S. and Uddin, K. M. S. 2006. In "Handbook on Agro technology". 4th ed., Bangladesh Agricukltural Res. Inst., Gazipur1701, Bangladesh, 356-358.

Hugar, A. H. and Nalawadi, U. G. 1999. Effect of growth regulators on morphological characters, flower production and seed yield of Gaillardia. Karnataka J. Agric. Sci., 12(1-4 combined): (226-229).

Khalighi, A, Hojati, Y., Babalar, M. and Naderi, R. 2005. Effects of nutrition solutions, cytokinin and soil texure on bulb growth, quality of bulb and number of bulblet in Drawin hybrid tulip Apeldoorn. Journal of Pajoush and Sazandegi., 73: 58-64.

Khandaker, M. M, Liyana, N., Majrashi, A., Dalorima, T., Alias, N.and Mat, N. 2018. Effects of kinetin on the morpho-physiological and biochemical characteristics of stevia (Stevia rebaudiana). Bulgarian J. Agri. Sci, 24(4): 638647.

Khatun, S, Roy, T. S., Haque, M. d. N. and Alamgir, B. 2016. Effect of Plant Growth Regulators and Their Time of Application on Yield Attributes and Quality of Soybean. International Journal of Plant \& Soil Science. 11(1): 1-9.
Krug, B.A.,Whipker, B.E., McCall, I. and Dole, J.M. 2006. Narcissus response to plant growth regulators. HortTechnology, 16: 129-32.

Kumari, S. 2017. Effect of Kinetin (6-FAP) and Cycocel (CCC) on Growth, Metabolism and Cellular Organelles in Pearl Millet (Pennisetum glaucum) Under Water Stress. Int.J.Curr.Microbiol.App.Sci. 6(8): 2711-2719.

Leshem, Y, Grossman, S., Frimer, A.and Zir, J. 1979. Endogenous Lipoxygenase control and lipid associated free redical scavenging as model of cytokinin action in plant senescence retardation. In. L. Aplequist and C. L. Liljenberg (eds) Advances in the biochemistry and physiology of plant Lipids, Vol. 3. Elisevier, Amsterdam. p. 193-198.

Maclean, D. C and Dedolph, R. R. 1962. Effects of N'-benzylaminopurine on postharvest respiration of Chrysanthemum morifolium and Dianthus caryophyllus. Bot Gaz 124: 20-21

Mansour, H. A., El Maadwy, A. I. and Mustafa, H. G. 2016. Effect of Irrigation Intervals and Cytokinin Treatments on Vegetative Growth of Conocarpus erectus L. Plants. Middle East J. Agric. Res., 5(3): 324-332.

Mara, C. G. 2017. Controlling growth in Echinacea Hybrids. Ph. D. Thesis, Virginia Polytechnic Institute and state University.

Mazher, A. A. M., Zaghloul, S. M., Mahmoud, S. A. and Siam, H. S. 2011. Stimulatory Effect of Kinetin, Ascorbic acid and Glutamic Acid on Growth and Chemical Constituents of Codiaeum variegatum L. Plants. AmericanEurasian J. Agric. \& Environ. Sci., 10 (3): 318323.

Mazrou, M.M. 1992. The growth and tropane alkaloids distribution in the different organs of Datura innoxia Mill. plants in relation to benzyladenine (BA) application. Menofiya J. Agric. Res., 17(4).

Menaka, P, Ashoka Rani, Y., Narasimha Rao, K. L., Hareesh Babu, P. and La Ahamed, M. 2018. Response of Chickpea (Cicer arietinum L.) to Foliar Application of Ethrel, Kinetin and Boron. Int.J.Curr.Microbiol.App.Sci. 7(11): 1653-1660.

Miller, C. O. 1956. Similarity of Some Kinetin and Red Light Effects. Plant Physiology, 31: 318.

Mohamed, Y. F.Y. 2017. Effect of some growth stimulants on growth, flowering and postharvest quality of aster (Symphyotrichum novi-belgii L.) cv. Purple Monarch. Middle East J. Agri. Res. 6(2): 264-273.

Neetu, R. K and Singh, A. K. 2016. Effect of different kinetin concentration on growth and flowering attributes in gladiolus cultivars. Agric. Sci. Digest., 36 (4); 319-322. 
Noor El-Deen, T. M., El-Sayed, B. A. and Shahin, S. M. 2014. Chrysanthemum and gaillardia as stunted winter annuals. ii. Blanket flower (Gaillardia pulchella pulchella.). Scientific J. Flowers and Ornamental Plants, 1(2):155-162.

Reda, F., El-Wahed, M. S. A. A. and El Din, K. M. G. 2010. Effect of indole acetic acid, gibberellic acid and kinetin on vegetative growth, flowering, essential oil pattern of chamomile plant (Chamomile recutita L. Rausch). world journal of Agricultural Sciences 6 (5): 595-600.

Riedell, W. E, Khoo, U.and Inglett, G. E. 1985. Effects of bio regulators on soybean leaf structure and chlorophyll retention. In: Plant Growth Regulation, Lake Alfred, Florida, Proceedings. Lake Alfred. 204-212.

Sachs, T. and Thimann, K. V. 1964, Release of lateral buds from apical dominance. Nature (Lond,), 20: 939-940.

Sachs, T and Thimann, K. V. 1967. The role of auxins and cytokinins in the release of buds from dominance. American Journal of Botany, 54: 136-144.

Sadak, S. M, Dawood, M. G., Bakry, B. A. and ElKaramany, M. F. 2013. Synergistic effect of Indole Acetic Acid and Kinetin on performance, some biochemical constituents and yield of faba bean plant grown under newly reclaimed sandy soil. Journal of Agricultural Sciences. 9 (4): 335-34.

Saffari, V. R., Khalighi, A., Lesani, H., Babalar, M. and Obermaier, J. F. 2004. Effects of different plant growth regulators and time of pruning on yield components of Rosa damascena Mill. Int. J. Agri. Biol., Vol. 6, No. 6.

Saifuddin. M, Hossain, A. B. M. S., Normaniza, O ., Nasrulhaq, B. A. and Moneruzzaman, K. M. 2009. The effects of naphthalene acetic acid and gibberellic acid in prolonging bract longevity and delaying discoloration of Bougainvillea spectabilis. Biotechnol. 8: 343350.

Salisbury, F. B and Ross, C.W. 1974. Plant Physiology. Publishing Inc. Belmont. California, 2nd ed., pp. 422.

Sardoei, A.S., Sarhadi, H., Rahbarian, P., Yazdi, M.R., Arbabi, M. and Jahantigh, M. 2013. Effect of gibberellic acid and benzyladenine growth regulators on offsets production of Aloe barbadensis at greenhouse conditions. Inter. J. Advanced Biolo and Biomed. Res., 1 (11): 1457-1465.

Schmulling, T. 2002. New insights into the functions of cytokinins in plant development. J. Plant Growth Regular., 21: 40-49.
Sharief, A. E and El-hamady, M. M. 2017. Influence of Growth Regulators on Shedding of Broad Bean, Growth, Yield and Seed Quality. International J. Envi, Agri and Biotec (IJEAB). 2(2).

Sharma, S and Farooqi, A. H. 1990. Effect of 2Chloroethyl phosphonic acid on economic yield of damask rose. Indian J. Agric. Sci., 60: 6912.

Shreedhar, D. 1993. Effect of growth regulators on growth and flower yield of gaillardia (Gaillardia pulchella F.) cv. Kanabargi Local. M.Sc. Thesis, Univ. Agri. Sci., Dharwad.

Shukla, A and Farooqi, A. H. 1990. Utilization of plant growth regulators in aromatic plant production. Curr. Res. Med. Arom. Plants, 12: 152-7.

Snedecor, G.W and Corchan, W.G. 1967. Statistical Methods. 6th Edition. Iowa State Univ. Press, Ames, Iowa, U.S.A.

Sorokin, H. and Thiamann, K.V. 1964 The histological basis for inhibition of axillary buds in Pisum salivum and the effects of auxins and kinetin on xylem development. Protoplasma, 59: 326-350.

Tamas, I. A. 1995. Hormonal regulation of apical dominance. In P. J. Davies ed., Plant Hormones: Physiology, Biochemistry and Molecular Biology. Second edition. Kluwer Academic Publishers, The Netherlands. 572597.

Yamaguchi, S. and Kamiya, Y. 2000. Gibberellin biosynthesis: Its regulation by endogenous and environmental signals. Plant Cell Physiology. 4: 251-257.

Youssef, A. S. M. 2004. Physiological studies on growth and flowering of Strelitzia reginae, Ait. Plant. Ph.D. Thesis Fac. Agric. Moshtohor, Zagazig.

Youssef, A. S. M. and Ismael, F. H. M. 2009. Response of Livia minister plant to light intensity and kinetin treatments Annals Of Agric. Sc., Moshtohor, Vol. 47(1): Ho. 29-44.

Zaghloul, M.A. 1998. Effect of paclobutrazol and benzyladenine on the vegetative growth and chemical composition or Codiaeum variegatum and Cordyline terminalis. Annals Agric. Sci,.Moshtohor, 36(4): 2447-2461.

Zhao, Z., Andersen, S.U., Ljung, K., Dolezal, K., Miotk, A., Schultheiss, S.J. and Lohmann, J. U. 2010. Hormonal control of the shoot stem-cell niche. Nature 465(7301): 1089.

Zidan, E. 1962. Evaluation of some Tomato lines in regard to leaf area efficiency and relation of partial defoliation to early and total yield fruit size, soluble solids, leaf rolling and blossom and rot. Ph. D. Thesis, Cornell Univ. Ithaca. New York, U.S.A. 


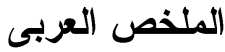

\section{دور البنزيل امينو بيورين والكينيتين فى تحسين نمو وإزهار ثلاثة أصناف من العنبر كثمير رامى جابر الكنانى'، عاطف محمد خضر نصار"، أحمد عامر الستاوى"

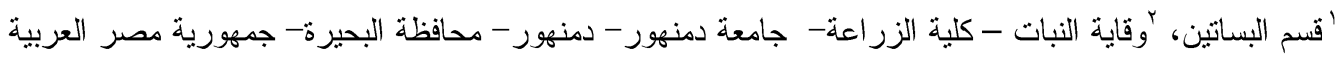

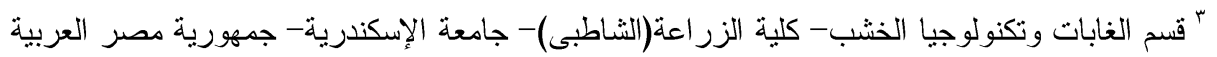

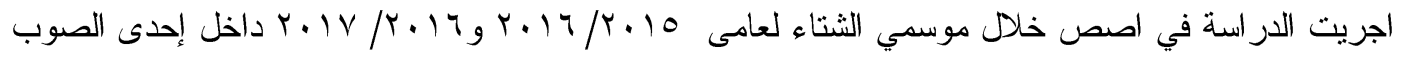

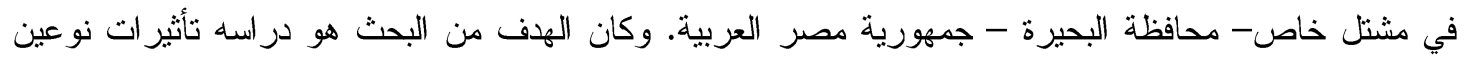

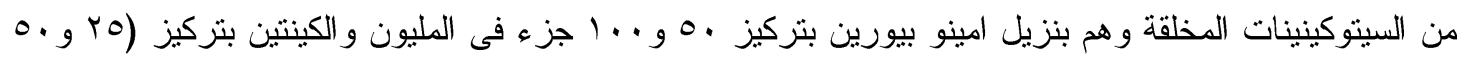

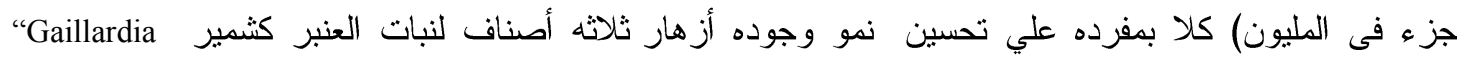
pulchella Pulchella, Mesa Yellow and Lorenziana" القطاعات المنثقه داخل نظام القطاعات كامله العشو ائية. وقد أظهرت النتائج المتحصل عليها خلا الموسمين بشكل

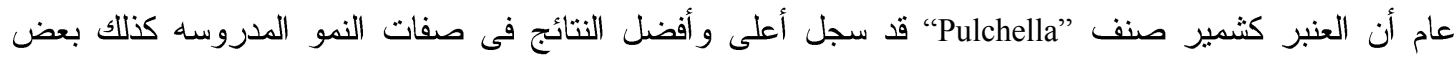

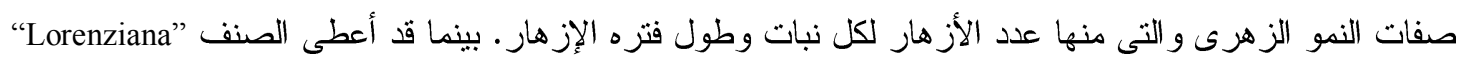

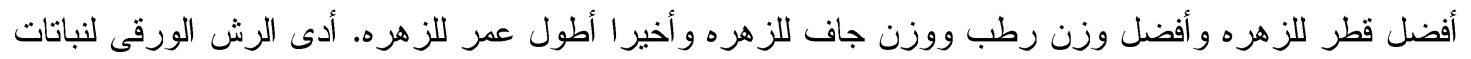

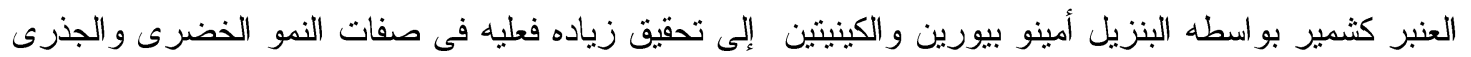

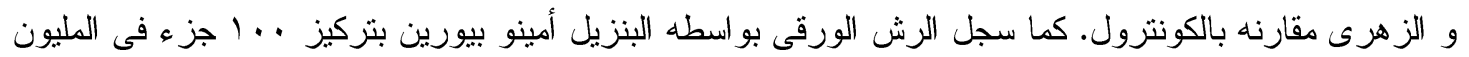

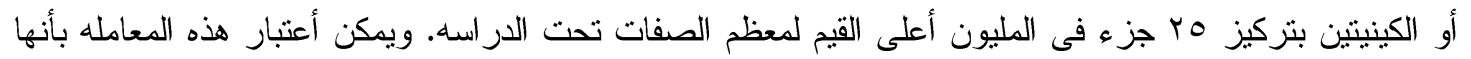

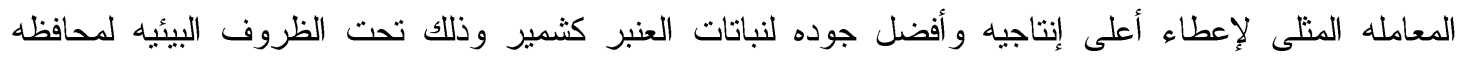
البحيره أو المناطق الأخرى الممانله لها. 